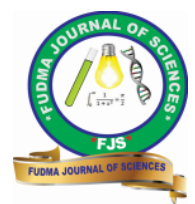

FUDMA Journal of Sciences (FJS)

ISSN online: $2616-1370$

ISSN print: 2645 - 2944

Vol. 4 No. 3, September, 2020, pp $285-291$

DOI: https://doi.org/10.33003/fjs-2020-0403-393

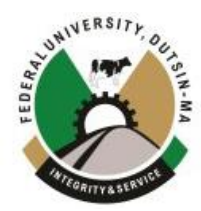

\title{
SURVEY OF FABRIC RE-DYEING ACTIVITIES AS A POTENTIAL ENVIRONMENTAL PROBLEM IN URBAN KANO, NIGERIA.
}

\author{
${ }^{* 1}$ Zainab Muhammad Sani, ${ }^{2}$ Aisha Sani Dalhatu and ${ }^{1}$ Ibrahim Lawal Abdullahi \\ ${ }^{1}$ Department of Biological Sciences, Bayero University, Kano, Nigeria \\ ${ }^{2}$ Department of Biological Sciences, Kaduna State University, Kaduna, Nigeria
}

Corresponding Author's email: zmsani.bio@buk.edu.ng

\begin{abstract}
A new re-dyeing practice has emerged and is fast spreading in urban Kano causing damage to the environment. This survey was carried out to assess selected fabric re-dyeing activity sites and their environmental impacts. This was achieved with the aid of designed questionnaire. Nine major dyeing sites in urban Kano: Kofar Mata, Chiranci, Karshen Waya, Rijiyar Zaki, Jan Bulo, Zawaciki, Kofar Na'isa, Karofin Zage and Goron Dutse dyeing pits were surveyed. The result revealed that individuals involved are males within the age range of $14-35$ years. The major sources of water are; pipe borne water, earthen dug wells and motorized borehole pumps. The dye wastewater is usually discharged untreated into street drains, ground surface and constructed pits. Individuals involved use protective measures such as face masks, hand gloves and traditional leather jackets. The dye powders, solutions and other constituents, when in contact with the skin cause serious burns, skin hardening and irritations. Inhalation of the gas emitted by the dye solution causes stomach upset and swelling of the body, which may sometimes be treated traditionally. The dye wastewater also destructs plantations/vegetation and inhibits survival of soil invertebrates such as earthworms. This calls for a general enlightenment to the users and general public on both the environmental and health risks of these substances.
\end{abstract}

Keywords: Dyeing, dyes, environmental impact, protective measures, wastewater.

\section{INTRODUCTION}

The growth of human population, urbanization and industrial production has transformed the environment across the globe. Nigeria being one of the most populated countries of Africa with nearly $40 \%$ residing in urban areas (El-ladan and Mudassir, 2018). According to Worldometer (2020) Nigeria's population is estimated at 207 million $(2.64 \%$ of the world's population), with an annual growth rate of $2.58 \%$. Urban cities in the country are increasing and expanding as a result of continuous migration from rural areas. The estimated population of urban area is 107 million (52\%) as reported by Worldometer (2020). The growth of human population in the country has significantly increased the rate of industrialization and technological development which has led to over exploitation of natural resources to rise living standard, and in the process causing serious damage to the environment to an extent that it is becoming unsafe for survival of humans and other living organisms (Lohchab and Saini, 2018).

Nigeria has a number of textile and spinning industries which use diverse chemicals in processing textile materials (Abdulmumini et al., 2014). The chemicals include inorganic compounds (such as sodium hydrosulphide and caustic sodium); organic compounds (the synthetic dyes); and polymers (like Azo dyes) (Liu, 2016). The dyes widely used in the process belong to different groups based on their application and chemical composition (Liu, 2016).

Kano is the most populous state with urban Kano having an estimated population of about 13.4 million (MNCH2, 2020).
Local textiles processing in Kano was introduced in the fifteenth century by the Moroccan traders, which led to the creation of the famous Kofar Mata dye pit in 1498 (Liman, 2015). The industry has been recognized for the dyeing of clothes using locally made colours from plant products and other substances (Barau, 2007, Renne, 2020). The dyed clothing then were referred as indigo-dyed (or adire by Yoruba) clothing materials (Renne, 2020). The demand for indigo-dyed clothing also led to the creation of other local indigo dyeing industries such as Karofin Zage, Karofin Sudawa, Karofin Kwalwa, Karofin Sheshe, Karofin Dala and Karofin Bagauda in the areas of old Kano city (Muhammadu, 2011). From the 1960s to 80s Kano became Nigeria's second largest industrial state after Lagos with the creation of four industrial estates (zones) namely: Bompai, Sharada, Challawa and the emerging new estates at Dakata (Mustapha, 2013). During, the 1970s when the country's economy had improved, fashionable cotton-printed textiles industries were created in Kano some of which include the Bagauda textile mills limited, Gaskiya textile mills limited, Adahama textile and garment limited, Kano textile printer, Nigeria spinners and dyers limited and Universal textiles (Gatawa et al., 2013). The introduction of the above mentioned industries resulted in the dwindling of the indigodyed clothing trade, as such; leading to collapse of most of the Kano dye pits with the exception of the Kofar Mata dye pit that is still functioning due to its ancient history and connection with Kano State Tourist Management Board (Renne, 2020). By the 1990s, textile industries Kano, Kaduna and Lagos have closed down, thus, textile materials were largely imported from countries like China, Germany, India, United kingdom, etc. (Muhammad et al., 2018). Muhammad (2010) reported that in 
the 1980s Kano had about 40 textile industries, but by the year 2003 , less than 10 were active. The collapse of the industries was as a result of many challenges that include poor power supply, unavailability of raw materials, lack of financial assistance from the government and importation of foreign goods (Yusuf, 2019).

A new dyeing practice emerged in the $21^{\text {th }}$ century in urban Kano which involves re-dyeing of print-cotton materials using synthetic dyes of different colour shades (Sani and Abdullahi, 2019). This was introduced as a result of textile industry collapse and the changing fashion for newer dyed clothing material (Renne, 2020). There are more than 30 outfits of these re-dyeing activity sites spread within local government areas of urban Kano (Sani et al., 2020). New textile materials and/or used clothes are changed to desired colour of the clients. The dyes used are mainly imported with brand names likes blue, yellow, red, etc. (their colour in appearance). These compounds are mixed in various concentrations as solutions to produce specific colour. The containers of these chemicals do not provide any information about the specific preparation, content and their concentration and the practitioners are generally unaware of the effects these substances may cause to humans, other living organisms and the environment as a whole (Sani, 2015).

Wastewater from the re-dyeing process is usually discharged on open spaces as well as surrounding soil and drains that subsequently flow to ditches, burrow pits, ponds and other habitats, thus, making receiving soils poor in physicochemical properties, susceptible to erosion, loss of productivity, sustainability and lowers food chain quality (Ahmad et al., 2012; Sani et al., 2018; Baba et al., 2020). There are areas particularly where the wastewater seeps into shallow community wells used for drinking and other domestic activities (Sani, 2015).

Dyeing is the process of adding colour to materials, such as textile fibers, yarns, and fabrics, so that the colouring matter becomes an integral part of the dyed material (Jayanth et al., 2011). Dyeing is normally done in a special solution containing dyes and particular chemical material. After dyeing, dye molecules have uncut chemical bond with fiber molecules, and about $10-20 \%$ of the dye remains in the dye bath which is discharged along with other residual chemicals as exhausted dye wastewater (Sajjala et al., 2008). The exhausted dye wastewater contains significant quantities of colouring matter which imparts colour to the receiving water bodies. In addition to imparting colour, dye wastewater also contributes to organic and inorganic load of the receiving streams. Most of these chemical compounds including the dyes are largely nonbiodegradable in the environment (Kamat and Kamat, 2015). Dye wastewaters are typically characterized by residual colour, alkaline $\mathrm{pH}$, excess TDS content, high COD with relatively low BOD values (Baba et al., 2020).

Another problem associated with these chemicals is their capacity to contaminate, cause harm and even damage or death to humans, animals, plants as well as other biotic systems over a period of time (Ortiz-Monsalve et al., 2017). The textile processes and dyeing in particular requires substantial quantity of water and most of it is subsequently returned in the form of wastewater or effluent and sludge (Soares et al., 2016). In Kano, the wastewaters are not treated or re-processed to remove the harmful or toxic substances before being discharged into the environment. The parts of the environment that subsequently receives these effluents are the land (soils) and aquatic systems (lakes, rivers, ponds, streams, etc). Living organisms including humans are susceptible to these dye substances depending on extent of exposure, their concentration in the environment, source and complexity of the organism (Sani, 2015). Similarly, the impact of the discharged wastewaters from this activity on land (soil) organisms, aquatic flora and fauna (species, composition, distribution and diversity), public health and environmental safety at present is not given due consideration (Baba et al., 2020). The survey is aimed at assessing selected re-dyeing activity sites and their environmental impacts in urban Kano.

\section{MATERIALS AND METHODS}

\section{Study Area}

Urban Kano is located at the central western part of Kano State between latitude $11^{\circ} 59^{\prime} 59.57^{\circ}-12^{\circ} 02^{\prime} 39.57^{\circ} \mathrm{N}$ of the equator and between longitudes $8^{\circ} 33^{\prime} 19.69^{\circ}-8^{\circ} 31^{\prime} 59.69^{\circ} \mathrm{E}$. It lies in the northern central boundary of Nigeria and is located some $840 \mathrm{~km}$ away from the edge of the Sahara desert and $1,140 \mathrm{~km}$ from the Atlantic Ocean. The Kano urban area covers $137 \mathrm{~km}^{2}$ (Oseiki, 2009).

\section{Sampling Sites}

A survey of the sites where this activity takes place was conducted using a GPS device (Garmin model-12, USA) and the geographical co-ordinates were recorded. Sampling sites includes; Kofar Mata $12^{\circ} 00^{\prime} 03^{\circ} \mathrm{N}-8^{\circ} 31^{\prime} 33^{\circ} \mathrm{E}$, Chiranci $11^{\circ} 57^{\prime} 25^{\circ} \mathrm{N}-8^{\circ} 27^{\prime} 57^{\circ} \mathrm{E}$, Karshen Waya $11^{\circ} 98^{\prime} 36^{\circ} \mathrm{N}$ $8^{\circ} 47^{\prime} 53^{\circ} \mathrm{E}$, Rijiyar Zaki $11^{\circ} 59^{\prime} 01^{\circ} \mathrm{N}-8^{\circ} 27^{\prime} 30^{\circ} \mathrm{E}$, Jan Bulo $11^{\circ} 97^{\prime} 97^{\circ} \mathrm{N}-8^{\circ} 46^{\prime} 57^{\circ} \mathrm{E}$, Zawaciki $11^{\circ} 55^{\prime} 21^{\circ} \mathrm{N}-8^{\circ} 27^{\prime} 60^{\circ} \mathrm{E}$, Kofar $\mathrm{Na}$ 'isa $11^{\circ} 58^{\prime} 56^{\circ} \mathrm{N}-8^{\circ} 30^{\prime} 54^{\circ} \mathrm{E}$, Karofin Zage $12^{\circ} 00^{\prime} 08^{\circ} \mathrm{N}-8^{\circ} 29^{\prime} 50^{\circ} \mathrm{E}$ and Goron Dutse $12^{\circ} 02^{\prime} 56^{\circ} \mathrm{N}$ $8^{\circ} 29^{\prime} 36^{\circ} \mathrm{E}$.

A participatory approach involving interview/discussion and visual observation according to Donald (2006) was employed to generate first-hand information needed.

\section{RESULTS}

The result obtained from responses from the interactions with individuals involved in dyeing activities through an interviewer questionnaire is presented below.

Dyeing process is usually temperature dependent. The process begins with the preparation of the dye solution. One kilogram of crystalline sodium hydrosulfide was placed in a container with $250 \mathrm{~g}$ of caustic soda; $100^{\circ} \mathrm{C}$ boiling water was immediately poured into the container to avoid cooling. $250 \mathrm{~g}$ of the dye powder to be used was then poured into the hot solution, making it ready for dyeing. The fabric to be dyed was soaked into the hot solution, swirled thoroughly for 510 minutes to obtain the desired colour preference, and then dried. Once the solution becomes relatively warm, it was discarded and a fresh one was prepared for subsequent use. Figure 1, shows that individuals engaged in dyeing activities are within the age range of $14-35$ years (males), with the age range of 26-35years having the highest number of individuals. 


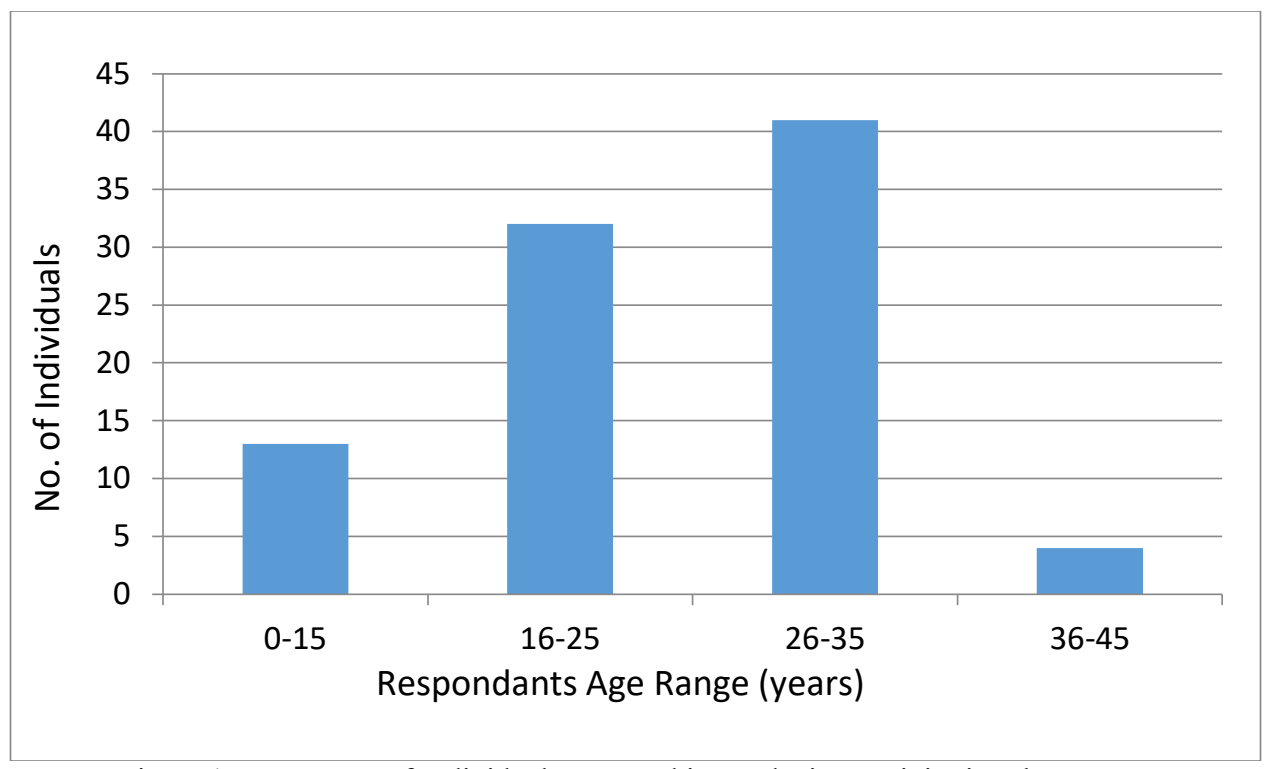

Figure 1: Age Range of Individuals Engaged in Re-dyeing Activity in urban Kano.

Figure 2, shows that the major sources of water used for these re-dyeing activities is the underground water (Earthen dug wells and Motorized borehole pumps). Earthen dug wells were found to have the highest usage (50\%), then Motorized borehole pumps $(30 \%)$, with pipe borne water having the least percentage $(20 \%)$.

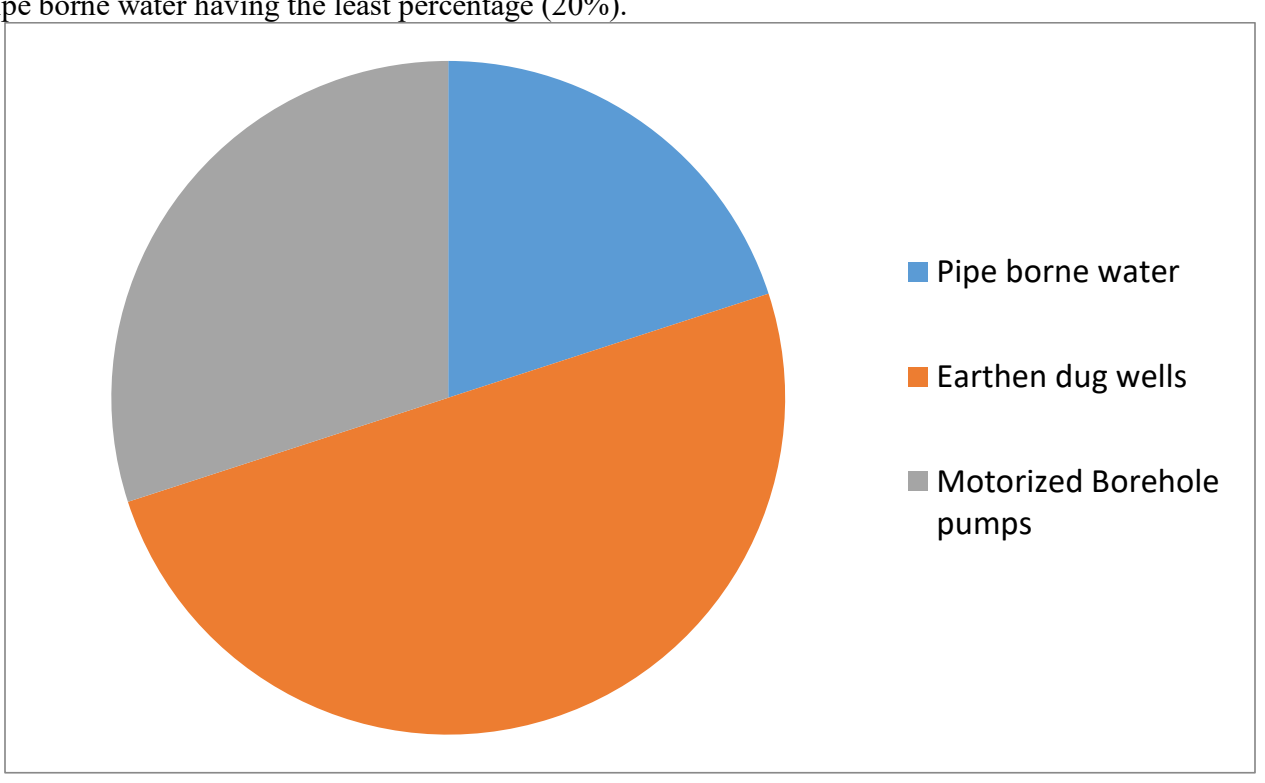

Figure 2: Sources of Water used for Re-dyeing Process in urban Kano.

Figure 3, shows nature of disposal of the dye wastewater, which reveals that most of the dye wastewater is discharged directly on the ground surface of the sites where these activities are taking place, some sites dispose theirs in street drains, while some very few sites construct pits for disposal of the dye wastewater. 


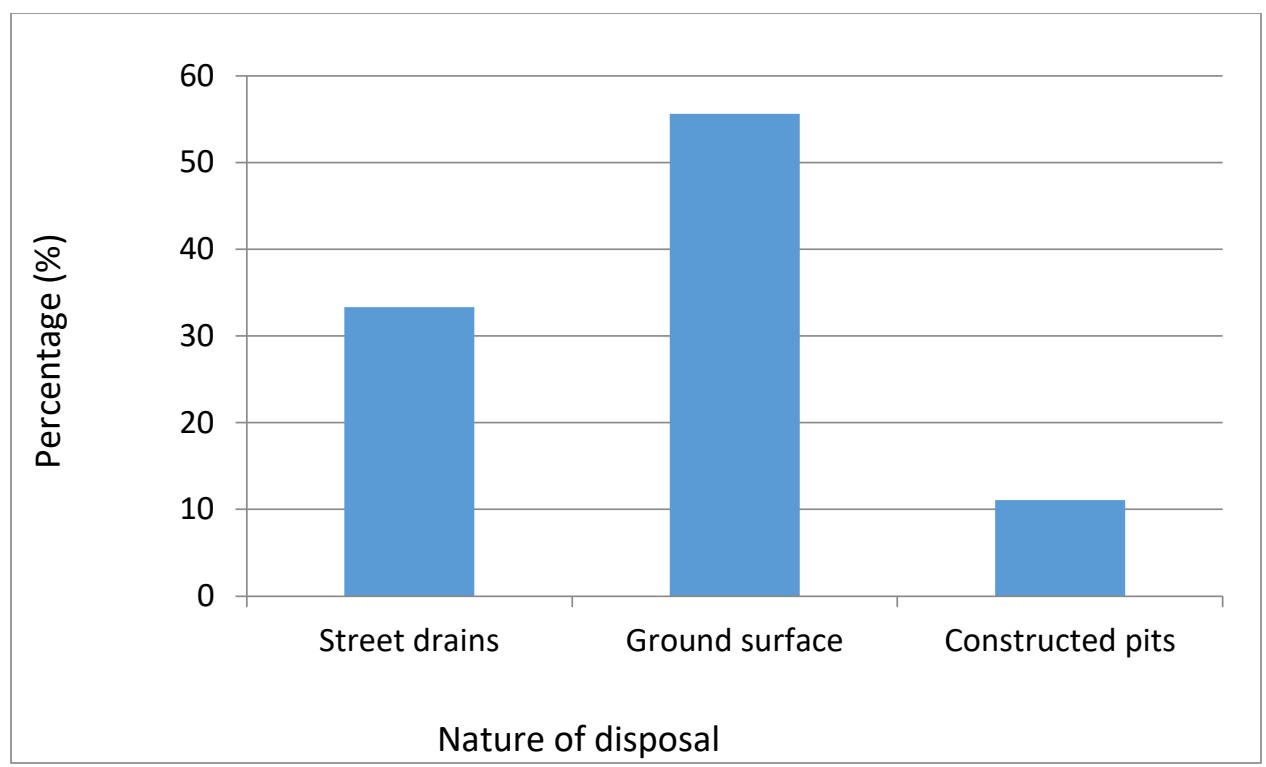

Figure 3: Nature of Disposal of Dye-wastewater

Figure 4, shows the major protective devices employed by the workers to secure themselves from damage caused by the dye substances. All the individuals in the sites surveyed were observed to be wearing hand gloves during the dye processing (100\%), $67 \%$ wear boots, $33 \%$ wear face masks and $22 \%$ wear leather jackets.

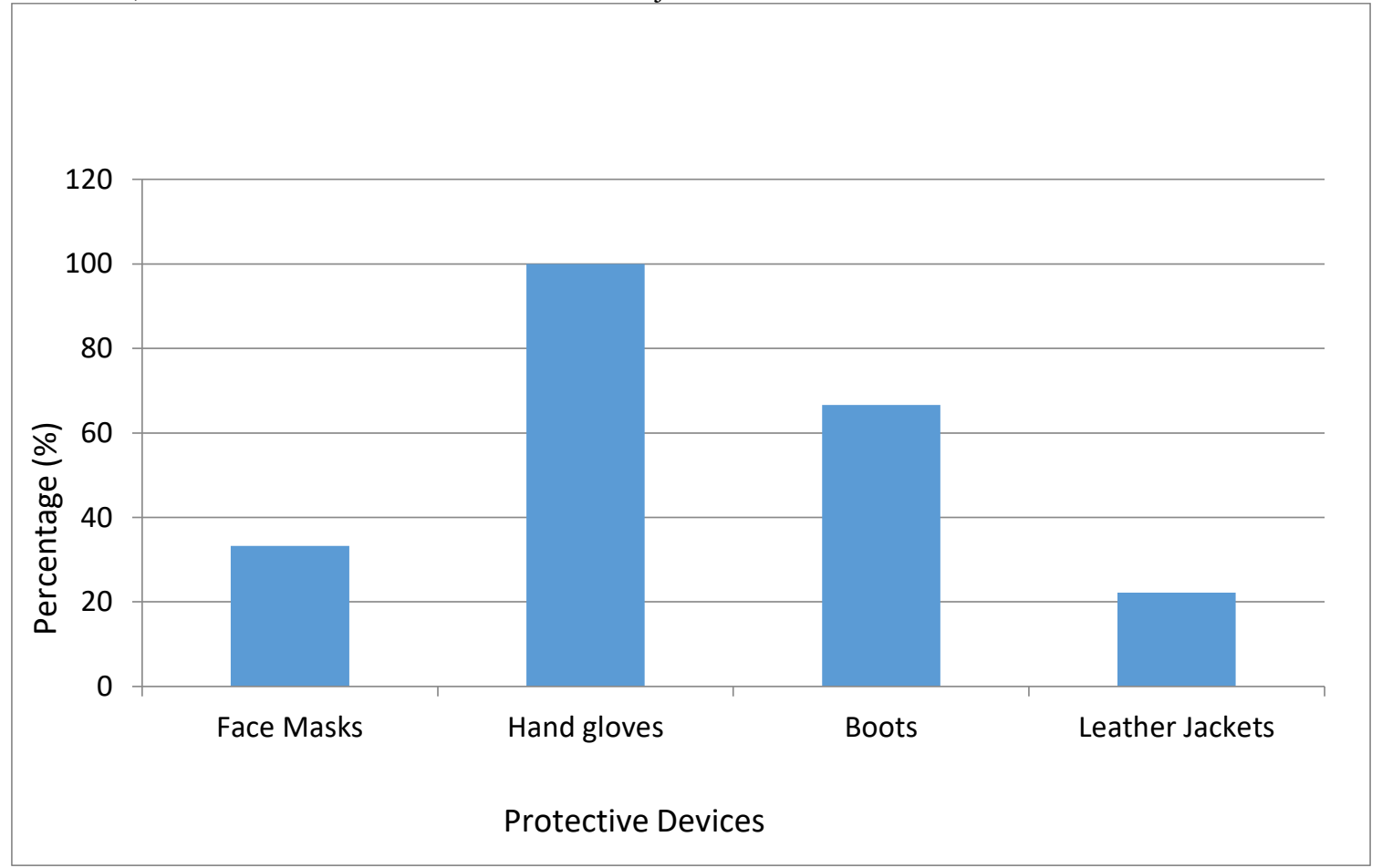

Figure 4: Protective Devices used by Re-dyeing Processing Activity Workers in urban Kano.

The major economic importance of this re-dyeing activity is environmental pollution. Areas where these activities are carried out are highly polluted due to the dye wastewater having the following chemical constituents; dyes, heavy metals (such as cadmium, chromium, lead, copper, etc.), salts (sodium hydroxide) and alkali (sodium hydrosulphide). The discharged wastewater pollutes both underground and surface water, as well as emits toxic gaseous substances causing air pollution. It also serves as a very reliable source of income to individuals involved, as such reducing the rate of unemployment, robbery, theft and other immoral activities conducted due to lack of jobs and other sources of income.

Some of the problems encountered in this activity involve; Lack of permanent and desirable sites as most of these activities are carried out on streets, road sides, homes, at the bank of ponds/pools, etc. This is because there is no provision by the government for lands where these activities can be carried out. Lack of constant water supply which is a general 
problem affecting the nation as a whole. Lack of adequate protective devices, as most of these devices are either traditionally made, or are devices specific to other activities and may not provide the desirable protection needed.

\section{DISCUSSION}

Re-dyeing activity has greatly contributed to the socioeconomic development of the community by reducing the rate of unemployment. Most of the individuals involved are contented and appreciate this dyeing activity, as they regard it as a work through which they earn their living. It is an informa business which is rarely supported by the government. The processes involved in fabric re-dyeing are energy demanding and risky which maybe the reason why individuals involved are mostly males (Sani, 2015). Pipe borne water, earthen dug wells and motorized borehole pumps are the main water sources that are used for all other activities (both industrial and domestic) in Kano and the nation as a whole (Sani, 2015). Most fabric re-dyeing sites create earthen dug wells because they are relatively cheap and provide high supply of water. The dye-wastewater is mostly untreated and discharged directly onto the ground floor which is due to lack of knowledge on strategies of its treatment and disposal. Also, there is no provision by the government for specific sites where such dyewastewater is to be disposed (Baba et al., 2020). The disposal of untreated dye-wastewater results in the loss of top soil and deforestation, loss of habitat species and biodiversity and degradation of wetlands (Isife, 2012). Ahmad et al. (2012) reported that discharge of dye-containing wastewater onto the soil or aquatic habitat makes it undesirable, because of the colour and presence of toxic products (generated due to chemical reaction of the dyes) that maybe carcinogenic or mutagenic to life forms. It also damages vital resources in the soil that support the survival of living organisms. Also, excess salts used in the dyeing process, to increase fixation of dyes to fibers, as well as heavy metal components of some dyes may adversely affect both soil and aquatic biota (Sani et al., 2020). Without adequate treatment these dyes and their associates can remain in the environment for a long period of time, thus, destroying the soil productivity (Nupur et al., 2012). The discharge of dye-wastewater may also increase the level of plant nutrients like sodium, calcium and potassium as well as other micronutrients and heavy metals which may result in complex interactions with natural binders in soils causing delay in the normal hydration reaction and release of heavy metals in ground water. It also increases $\mathrm{pH}$ levels, sodicity and electric conductivity of the soil (Saleem et al., 2011; Sani et al., 2020).

The rate at which protective devices are being used by individuals involved in these activities to prevent damage to their body is very low. This is because individuals are careless and unaware of the toxicity of the compounds contained in the dyes. Most of the individuals (about 90\%) do not visit hospitals or nearby clinics in case of any damage by the dye solution (either by skin/eye contact or inhalation), rather they use their traditional ways of treatment (Sani, 2015). For example, a victim of inhalation, drinks a lot of milk, this is said to prevent stomach upset and swelling of the body. Skin burns and irritations are treated using herbs and other traditional medicines. Accumulation of dyes and associates in human and animal tissues through uptake or direct contact may affect the kidney, brain cells and permeability of liver membrane
(Sharma et al., 2009). The dyes have been reported to causes allergic dermatoses, contact dermatitis, asthma and change in immunoglobulin levels of individuals exposed (Sani et al., 2018). Previous studies have also shown increased risks of colon, bladder and rectum cancers which may be related to accumulation of dyes due to long time exposure (Birhanli and Ozmen, 2005).

Animals do not graze around these re-dyeing areas, and if they do, do not consume the wastewater (Sani, 2015). Consequently, the release of large quantities of dyes into aquatic habitats makes the survival of fishes and other lives difficult depending on their structural complexities and metabolic efficiency (Nupur et al., 2012). Kumar et al. (2007) also reported that release of dye-wastewater contaminates environment, cause harm and even damage or death to humans, animals and plants as well as other biotic systems over time.

\section{CONCLUSION}

In conclusion, the result of the survey indicated that even though re-dyeing activity has contributed greatly to the socioeconomic development of urban Kano, it is contaminating the environment and causing serious risk to human lives and other living organisms through ecological interaction. The dyewastewater contaminates aquatic systems and destructs soil fertility due to its colour and toxic compounds, thus, inhibiting the growth and survival of most organisms found in these habitats. There are areas particularly where this wastewater seeps into shallow community wells used for drinking and other domestic activities. Similarly, individuals involved are mostly adult males who are unaware of the impacts of these compounds to their health and the environment as a whole.

\section{RECOMMENDATION}

A study on soil organisms or microflora and fauna; aquatic biota and human exposed to these substances is needed in urban Kano so as to obtain data that could provide some insight on risks associated with this expanding industrial activity.

\section{ACKNOWLEDGEMENTS}

The authors thank all the lecturers and Laboratory technologists of Faculty of Life Sciences, Bayero University Kano for their hospitality and assistance.

\section{REFERENCES}

Abdulmumini, A., Gumel, S.M. and Jamil, G. (2014). Industrial Effluents as Major Source of Water Pollution in Nigeria: An Overview. American Journal of Chemistry and Applications, 1(5): 45-50.

Ahmad, M.T., Sushil, M. and Krishna, M. (2012). Influence of Dye Industrial Effluent on Physicochemical Characteristics Properties of Soil at Bhairavgarh, Ujjain, MP, India. Research Journal of Environmental Sciences, 1(1): 50-53.

Baba, A., Garba, S.T., Kolo, B. and Bello, H.S. (2020). Bioremediation of Effuents Samples from Textile Industry in Kano State, Nigeria. Chemistry Research Journal, 5(1): 56-70.

Barau, A.S. (2007). The Great Attractions of Kano Research and Documentation Directorate, Government House Kano, 1178 . 
Birhanli, A. and Ozmen, M. (2005). Evaluation of Toxicity and Teratogenity of Six Commercial Textile Dyes Using the Frog Embryo Teratogenesis Assay - Xenopus. Drug and Chemical Toxicologies, 28: 51-65.

Donald, Y.O. (2006). Assessment of Kofar Mata Dye Pits (KMDP) as a Sustainable Tourist Attraction in Kano - Nigeria. Biol. \& Environ. Sci. J. for the Tropics, 3(1): 37-41 ISSN 0794 9057.

El-ladan, I.Y. and Mudassir, H. (2018). Urbanization and its Impacts in Nigeria: A Review. A Text of Paper Presented at the $20182^{\text {nd }}$ Postgraduate Seminar Series of the Department of Geography, Umaru Musa 'Yar-adua University, held at the Departmental GIS Laboratory on Wednesday, $7^{\text {th }}$ March, 2018.

Gatawa, N.M., Aliyu, C.U. and Musa, S. (2013). Impact of Globalization on Textile Industries: A Case Study of some Nigerian Industries in Kano Metropolis. European Scientific Journal, 9(2): 1-23.

Isife, C.T. (2012). Environmental Problems in Nigeria - A Review. Sustainable Human Development Review, 4(1 \& 2): 118.

Jayanth, S.N., Karthik, R., Logesh, S., Srinivas, R.K. and Vijayanand, K. (2011). Environmental Issues and its Impacts Associated with the Textile Processing Units in Tirupper, Tamilnadu. $2^{\text {nd }}$ International Conference on Environmental Science and Development IPCBEE. 4: 1-5.

Kamat, D.Y. and Kamat, S.D. (2015). Bioremediation of Industrial Effluent Containing Reactive Dyes. International Journal of Environmental Sciences, 5(6): 0976-4402.

Kumar, P., Prasad, B., Mishra, I.M. and Chand, S. (2007). Catalytic Thermal Treatment of Desizing Wastewater. Hazardous Material, 149: 26-34.

Liman, M.A. (2015). A Spatial Analysis of Industrial Growth and Declinein Kano Metropolis, Nigeria. Ph.D. Thesis Submitted to the School of Postgraduate Studies, Ahmadu Bello University, Zaria, Kaduna, 1-160.

Liu, Y. (2016). Reactive Dye Dimerization for Enhanced Affinity to Cotton Fibers. M.Sc. Thesis Submitted to the Graduate Faculty of North Carolina State University, Raleigh, North Carolina, 1-120.

Lohchab, R.K. and Saini, J.K. (2018). Industrial Pollution Management. IAHRW Publications Private Limited, Gurugrum, Haryana, 1-92.

MNCH2 (2020). Maternal, Newborn and Child Health Programme, www.mnch2.com (Retrieved 24 ${ }^{\text {th }}$ March, 2020).

Muhammad, M. (2010). Globalization and Nigerian Textile Factories: An Analysis of Three Kano Textile factories, Unpublished M.Sc. Dissertation Submitted to the Department of Political Sciences, Bayero University, Kano, Nigeria.
Muhammad, M., Buba, R., Agboola, Y.H. and Lola, G.K. (2018). Nigeria Textile Industry: Evidence of Policy Neglect. Sarjana, 33(1): 40-56.

Muhammadu, U.A. (2011). Historical Origins of Kano, Retrieved from http://www.kanoonline.com/jmqs/index.php/history/historicalorigins-of-kano.

Mustapha, H.B. (2013). Management of Industrial Effluents: A Review of the Experiences in Kano, Northern Nigeria. International Journal of Advanced Research, 1(4): 213-216 ISSN No. 2320-5407 (http://www.journalijar.com).

Nupur, M., Pradeep, B. and Pratibha, S. (2012). Review of the Mutagenicity of Textile Dye Products. Universal Journal of Environmental Research and Technology, 2(2): 1-18.

Ortiz-Monsalve, S., Dornelles, J., Poll, E., Ramirez-Castrillon, M., Valente, P. and Gutterres, M. (2017). Biodecolourization and Biodegradation of Leather Dyes by a Native Isolate of Trametes villosa. Process Safety and Environmental Protection, 109: $437-451$.

Oseiki, A.O. (2009). The Influence of Gender on Intra-urban Transportation: A Case Study of Kano Metropolis. Unpublished Undergraduate Project Submitted to Department of Geography, Ahmadu Bello University, Zaria.

Renne, E.P. (2020). Reinterpreting Adire Cloth in Northern Nigeria. Textile History, Pasold Research Fund Limited, 1-26.

Sajjala, S.R., Bijjam, K. and Nanaga, S.P.R. (2008). Color Pollution Control in Textile Dyeing Industry Effluents Using Tannery Sludge Derived Activated Carbon. Bull. Chem. Soc. Ethiop., 22(3): 369-378.

Saleem, M., Chakrabarti, M.H., Irfan, M.F., Hajimolana, S.A., Hussain, M.A., Diya'uddeen, B.H. and Daud, W.M.A.W. (2011). Electrokinetic Remediation of Nickel from Low Permeability Soil. International Journal of Electrochemical Science, 6: 4264-4275.

Sani, Z.M. (2015). An Eco-toxicological Study of Dyes and Dye Wastewater from Dyeing Activities in Urban Kano, Nigeria. M. Sc. Dissertation Submitted to the Department of Biological Sciences, Bayero University, Kano, 1-109 (Unpublished).

Sani, Z.M. and Abdullahi, I.L. (2019). An Impact Assessment of Dye-wastewater of Selected Sites in Urban Kano, Nigeria. BAJOPAS, Special Conference Edition, November, 2019, 12(1): 486-492.

Sani, Z.M., Abdullahi, I.L. and Sani, A. (2018). Toxicity Evaluation of Selected Dyes Commonly used for Clothing Materials in Urban Kano, Nigeria. Eur Exp Biol, 8(4): 26-30.

Sani, Z.M., Dalhatu, A.S., Namadina, M.M. and Abdullahi, I.L. (2020). Impact Assessment of Dyeing Processing Activity on soils of Selected Sites in Kano Metropolis, Nigeria. DUJOPAS, 6(1): 219-225. 
Sharma, R.K., Agrawal, M. and Marshall, F.M. (2009). Heavy Metal in Vegetable Collected from Production and Market Sites of a Tropical Urban Area of India, Food Chem.. Toxicol., 47: 583.

Soares, P.A., Souza, R., Soler, J., Silva, T.F.C.V., Souza, S.M.A.G.U, Boaventura, R.A.R. and Vilar, V.J.P. (2016). Remediation of a Synthetic Textile Wastewater from Polyestercotton Dyeing Combining Biological and Photochemical Oxidation Processes. Separation and Purification Technology, 172(2017): 456-462.
Worldometer (2020). Nigeria Population. United Nations, Department of Economic and Social Affairs, Population Division. World Population Prospects: The 2019 Revision. Retreived on $1^{\text {st }}$ September, 2020 from www.worldometers.info

Yusuf, K.M. (2019). Collapse of Textile Industry in Nigeria: A Study of Kano State, Nigeria. M.Sc. Dissertation Submitted to the School of Postgraduate Studies, Ahmadu Bello University, Zaria, 1-99. 